\title{
The after-effect of paclobutrazol on morphological characteristics of in vitro Narcissus poeticus ssp. radiiflorus plants
}

\author{
Jevesák, M., Ördögh, M. \& Jámbor-Benczúr, E. \\ Corvinus University Budapest, Faculty of Horticultural Science, Department of Floriculture and Dendrology, \\ H-1118 Budapest, 35-43. Villányi str., Hungary, *Fax: + 361482 6333, E-mail: mate.ordog@uni-corvinus.hu
}

\begin{abstract}
Summary: After different pre-culturing period (12, 23 or 34 days) on $1 / 2$ MS medium with 1 mg ${ }^{-1}$ paclobutrazol, 1 mg $\mathrm{l}^{-1} \mathrm{~N}^{6}$ benzyladenine and $0.1 \mathrm{mg} \mathrm{l}^{-1} 1$ - naphthaleneacetic acid , 3 groups of Narcissus poeticus ssp. radiiflorus bulb scales were kept on the same medium without hormones. The results were evaluated monthly and the final one happened after 7 month. The best results were achieved due to the shortest pre-culturing period (12 days; Group 1), with 4.9 bulblets and $4.54 \%$ hyperhydricity. The result of the second treatment (pre-culturing period of 23 days; Group 2) was not different significantly but the number of bigger bulblet were higher (4.54 bulblets). After the longest pre-culturing period (34 days; Group 3), the number of bulblets was low (3.68) and more hyperhydricity (18.18\%) was detected. The highest number of roots (13.91) was observed in this group very likely due to the strong after-effect of paclobutrazol.
\end{abstract}

Keywords: paclobutrazol, multiplication, hyperhydricity, Narcissus

\section{Introduction}

Narcissus poeticus ssp. radiiflorus is a nice bulbous perennial (suitable as ornamental plant) with narrower leaves and short, reddish-orange lateral perianthiums (Chopik et al., 1977; Matvejev, 1980). This plant (which represented as several synonyms in the IUCN Red List of Threatened Species of Ukraine: N. angustifolius, N. poëticus ssp. angustifolius, $N$. poëticus ssp. radiiflorus, $N$. poëticus ssp. stellaris) is an actually endangered subspecies with disjunct areas, occur in Albaina, Hungary, Romania. The largest population was found in the Daffodils' Valley (a unique natural wilderness reserve protected by UNESCO), near Khust in Transcarpatia (Ziman \& Bulah, 2009), Ukraina. In Hungary, it is a rare, protected plant which can be found only in West and South Transdanubia. Harvesting of beautiful flowers also prohibited in Ukraine despite the higher habitat (Artemchuk et al., 1966; Chopik, 1976; Kostenko \& Sheljag-Sosonka, 1996).

Paclobutrazol (PB) was effectively used mainly for stimulating multiplication or in vitro rooting in the case of different ornamental plants, like Digitalis obscura (Gavidia \& PérezBermúdez, 1997), Gladiolus (Nagaraju et al., 2002), Hemerocallis (Chen et al., 2005), Syringa $x$ hyacinthiflora (Hongxia et al., 2009) and some close relatives belong to the Amaryllidaceae family, for example Leucojum aestivum (Jevcsák et al., 2012) and Galanthus elwesii (Mosonyi et al., 2013).

Only few data are available in the literature concerning PB application in the micropropagation of Narcissus. Chamani et al. (2012) used different concentration of PB during micropropagation of unspecified Narcissus. Significantly the highest bulb and root number was achieved on medium containing $2 \mathrm{mg} \mathrm{l}^{-1} \mathrm{~PB}$, and $\mathrm{PB}$ at all concentrations decreased the leaf production. For shoot multiplication of radiiflorus subspecies of $N$. poeticus, $1 \mathrm{mg} \mathrm{l}^{-1} \mathrm{~N}^{6}$-benzyladenine (BA) $+0.25 \mathrm{mg} \mathrm{l}^{-1} \mathrm{~PB}+0,1 \mathrm{mg} \mathrm{l}^{-1} 1$-naphtaleneacetic acid (NAA) combination was optimal, but hyperhydricity and $70 \%$ rooting were obtained (Jevcsák et al., 2013). In another trial (Jevcsák et al., 2014) effects of PB and/or NAA were studied. The highest root number (6.2) and the best weight of bulbs $(1.8 \mathrm{~g})$ were detected in the case of using $0.2 \mathrm{mg} \mathrm{l}^{-1}$ NAA. As for rooting and bulb formation, the combination of PB and NAA $\left(0.1+0.1 \mathrm{mg} \mathrm{l}^{-1}\right)$ proved to be worse than the effect of NAA alone, but better than the media with only PB. However, combined application of PB and PB + NAA resulted in the longest leaves $(32.99 \mathrm{~mm})$ but a higher PB concentration caused deformation.

The aim of our present study was to decrease the rate of hyperhydricity (with lower concentration of paclobutrazol) and to find an efficient method for in vitro multiplication of Narcissus poeticus ssp. radiiflorus.

\section{Materials and methods}

The experiments were carried out from sterile bulbs (sized 8-10 $\mathrm{mm}$ diameter) originated from the previous in vitro works in the laboratory of the Department of Floriculture and Dendrology, Corvinus University Budapest. 
On January $18^{\text {th }} 2012$, bulbs were cut in four equal segments (10-12 mm) and placed into $100 \mathrm{ml}$ Erlenmeyer flasks containing half-strength (1/2) MS medium (Murashige \& Skoog, 1962) supplemented with $1 \mathrm{mg} \mathrm{l}^{-1} \quad \mathrm{~N}^{6}$ benzyladenine (BA), $1 \mathrm{mg} \mathrm{l}^{-1}$ paclobutrazol (PB), 0,1 $\mathrm{mg} \mathrm{l}^{-1}$ 1-naphtaleneacetic acid (NAA) and $30 \mathrm{~g} \mathrm{l}^{-1}$ sucrose, $11 \mathrm{~g} \mathrm{l}^{-1}$ agar (Reanal). The $\mathrm{pH}$ adjusted to 5.6 with $\mathrm{KOH}$. The media were autoclaved on $10^{5} \mathrm{~Pa}$ pressure for 30 minutes.

Three groups ( $3 \times 22$ bulb clusters) were separated. These plants were transferred to hormone-free $1 / 2 \mathrm{MS}$ medium (containing as much sucrose and agar) after 12 (Group 1), 23 (Group 2) and 34 (Group 3) days. Culture conditions were: $23{ }^{\circ} \mathrm{C}, 16 / 8 \mathrm{light} /$ dark photoperiod $\left(37.2 \mu \mathrm{mol} \mathrm{m} \mathrm{m}^{-2} \mathrm{~s}^{-1}\right.$ photosynthetic photon flux density).

Morphological characteristics (the number and length of shoots and roots, vitrification rate) were recorded six times (from $27^{\text {th }}$ March to $21^{\text {st }}$ September, 2012). Data were evaluated by ROPStat statistical software (Vargha, 2002, 2008). Means comparison were done by using GamesHowell, Tukey-Kramer tests at $\mathrm{p}<0.01$. Each experiment was replicated twice.

\section{Results and discussion}

Plantlets of the of the Group 1 (Table 1) produced the highest number of bulblets from $27^{\text {th }}$ April to $29^{\text {th }}$ May. But in September, increasing of proliferation was detected in the other two groups of plantlets and there was significant difference between values of the Group 1 (4.9) and Group 3 (3.68). As the number of bulblets was the highest in the Group 1 and 2, the hyperhydricity of bulblets proved to be lower (4.5 and $9 \%$ respectively), similarly as in the previous experiments (15-30\%, Jevcsák et al., 2013).

The root number was the highest on plants of Group 3 almost in every sampling time between $27^{\text {th }}$ April and $21^{\text {st }}$ September). The most roots (13.91) were achieved by September after 34-day-long pre-culturing period (Group 3). Root length was measured only at the last sampling time $\left(21^{\text {st }}\right.$ September) and averagely the longest roots $(41.19 \mathrm{~mm})$ were observed in the Group 1 (date were not shown). There was no positive correlation between the length of pre-culturing period and root length whereas in our earlier trial (Jevcsák et al, 2013) PB in every concentration shortened the roots (2.9-4.75 mm) and lack of PB resulted in significantly longer roots $(8.68-33.88 \mathrm{~mm})$.

All (100\%) plantlets of Groups 1 and 2 developed roots (Figure 1) by the end of the observation period. The maximal rooting percentage was $77.27 \%$ when plants were cultured previously for the longest period on medium with PB (Group 3). As it was described previously, PB was not efficient for rooting especially in the case of higher concentration $\left(2.5 \mathrm{mg} \mathrm{l}^{-1}\right)$, and the best results (100\% rooting and averagely 9.85 roots) were obtained on hormone-free medium (Jevcsák et al., 2013).

The hyperhydrated bulblets were found first at the second sampling time $\left(27^{\text {th }}\right.$ April). By the next sampling time $\left(8^{\text {th }}\right.$ May) the percentage of hyperhydricity was increased (up to $31.81 \%$ ), but no more changes were observed until $19^{\text {th }}$ June. At the time of final sampling ( $21^{\text {st }}$ September) values of hyperhydricity in every group decreased (4.54-18.18\%, Figure 2). Consequently, after-culturing on hormone-free $1 / 2$ MS medium resulted in lower hyperhydricity in spite of applying more BA and PB in the pre-treatment. In another trial (Jevcsák et al, 2013) lower concentration of BA and $\mathrm{PB}\left(0.5+0.25 \mathrm{mg} \mathrm{l}^{-1}\right.$ instead of $\left.1+1 \mathrm{mg} \mathrm{l}^{-1}\right)$ resulted in more hyperhydrated bulblets (15-30\%) when plantlets were cultured on BA + PB-containing medium continuously (without a rest period on hormone-free medium). In our study, lower hyperhydricity was achieved if every groups were transferred to hormone-free medium earlier (i.e. hyperhydratation \% was the lowest in the Group 1 and the highest in the Group 3).

Table 1. Average number of bulblets and roots of in vitro N. poeticus subsp. radiiflorus

\begin{tabular}{|c|c|c|c|}
\hline $\begin{array}{c}\text { Data of } \\
\text { examination } \\
\text { (2012) }\end{array}$ & Group & $\begin{array}{c}\text { Average } \\
\text { bulblet number } \pm \text { SD }\end{array}$ & $\begin{array}{c}\text { Average root } \\
\text { number } \pm \text { SD }\end{array}$ \\
\hline 27th March & 1. & $0.95 \pm 1.21 \mathrm{a}$ & $1.54 \pm 2.11 \mathrm{a}$ \\
\hline & 2. & $0.5 \pm 0.8 \mathrm{a}$ & $1.09 \pm 1.5 \mathrm{a}$ \\
\hline & 3. & $0.4 \pm 0.66 \mathrm{a}$ & $0.54 \pm 1.22 \mathrm{a}$ \\
\hline 27th April & 1. & $1.31 \pm 1.17 \mathrm{a}$ & $2.72 \pm 2.27 \mathrm{a}$ \\
\hline & 2. & $1.18 \pm 1.29 \mathrm{a}$ & $2.54 \pm 2.08 \mathrm{a}$ \\
\hline & 3. & $1.68 \pm 1.64 \mathrm{a}$ & $3.4 \pm 3.2 \mathrm{a}$ \\
\hline 8th May & 1. & $1.9 \pm 1.3 \mathrm{a}$ & $4.59 \pm 2.93 \mathrm{a}$ \\
\hline & 2. & $1.86 \pm 1.39 \mathrm{a}$ & $4.4 \pm 3.2 \mathrm{a}$ \\
\hline & 3. & $2.54 \pm 2.13 \mathrm{a}$ & $6.54 \pm 6.37 \mathrm{a}$ \\
\hline 29th May & 1. & $2.4 \pm 1.36 \mathrm{a}$ & $6.13 \pm 3.72 \mathrm{a}$ \\
\hline & 2. & $2.27 \pm 1.63 \mathrm{a}$ & $5.09 \pm 3.63 \mathrm{a}$ \\
\hline & 3. & $2.95 \pm 2.25 \mathrm{a}$ & $8.36 \pm 8.28 \mathrm{a}$ \\
\hline & 1. & $3.22 \pm 1.41 \mathrm{a}$ & $7.72 \pm 2.41 \mathrm{a}$ \\
\hline & 2. & $2.63 \pm 1.56 \mathrm{a}$ & $5.63 \pm 3.59 \mathrm{~b}$ \\
\hline & 3. & $3.13 \pm 1.78 \mathrm{a}$ & $9.04 \pm 8.34 \mathrm{ab}$ \\
\hline & 1. & $4.9 \pm 1.37 \mathrm{a}$ & $8.71 \pm 2.83 \mathrm{a}$ \\
\hline & 3 th June & $3.68 \pm 1.46 \mathrm{~b}$ & $13.91 \pm 8.55 \mathrm{~b}$ \\
\hline
\end{tabular}

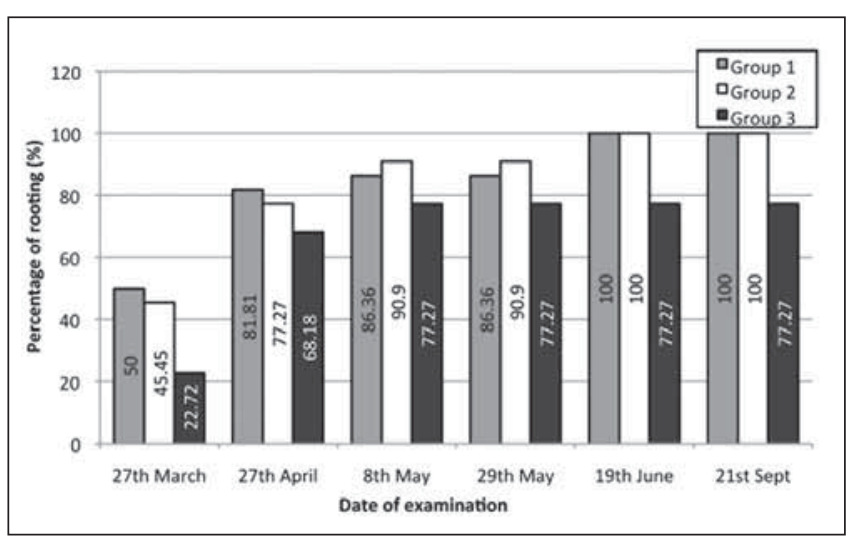

Figure 1. Rooting rate of in vitro Narcissus poeticus subsp. radiiflorus 


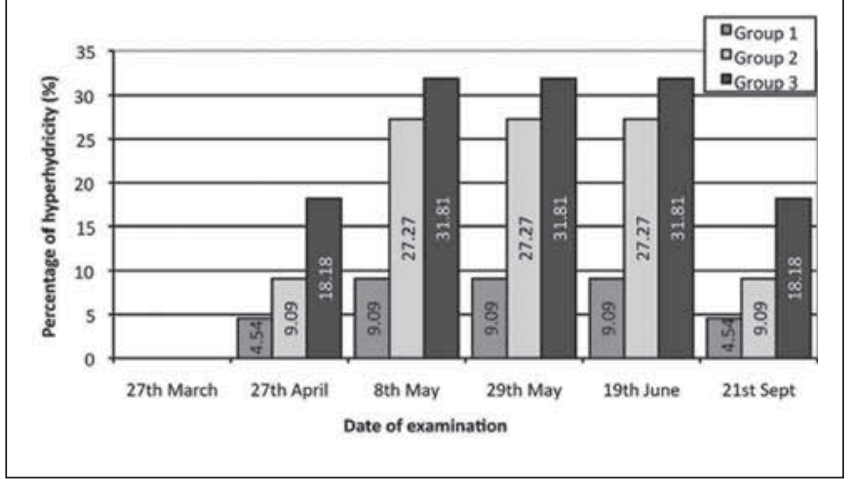

Figure 2. Rate of hyperhydrated bulblets of in vitro Narcissus poeticus subsp. radiiflorus

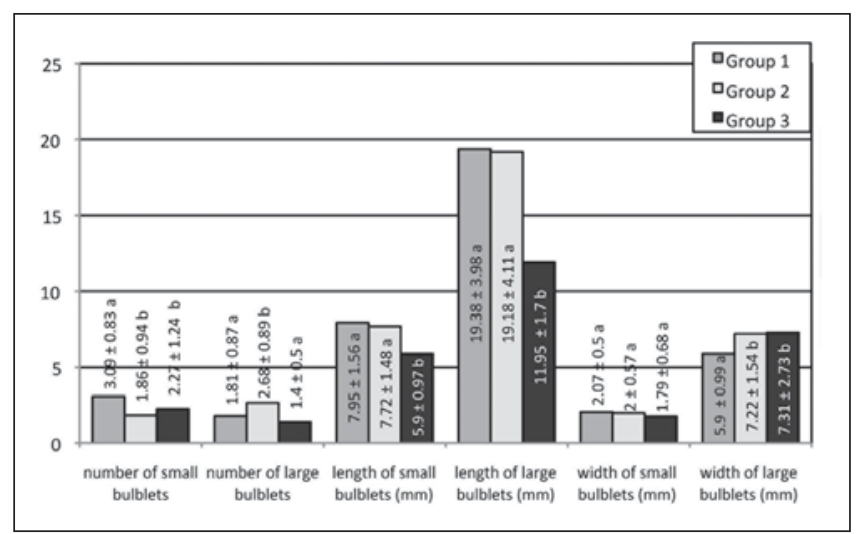

Figure 3. Small and large* bulblet characteristics of in vitro Narcissus poeticus subsp. radiiflorus on $21^{\text {st }}$ Sept $\left({ }^{*}\right.$ small: shorter than $9 \mathrm{~mm}$, large: longer than $10 \mathrm{~mm}$ )

At the last sampling time $\left(21^{\text {st }}\right.$ Sept $)$, bulblets were separated according to their sizes (Figure 3). The highest number of small bulblets was found in the Group 1 (3.09), and same result of large ones was detected in the Group 2 (2.68). Jevcsák et al. (2013) found more (2.35-7.75) small bulblets on every medium (except for the hormone free one), although PB was not suitable for producing more ones, because higher concentration $\left(2.5 \mathrm{mg} \mathrm{l}^{-1}\right)$ of PB significantly decreased multiplication.

Length of small and large bulblets was the highest in the Group 1 and the lowest in the Group 3. Additionally, large bulblets became wider (7.31 $\mathrm{mm}$ in Group 3), and the maximum small bulblets width was only $2.07 \mathrm{~mm}$ in the Group 1. Thus, longer time of pre-treatment (on medium + $\mathrm{PB}, \mathrm{BA}$ and NAA) resulted in shorter and narrower bulblets (Figure 4).

Summarizing, if the pre-culturing period was too long, paclobutrazol decreased the number of bulblets (4.9-3.68) and increased hyperhydricity (4.54-18.18). According to the after-effect, this growth retardant increased the bulblet number in the case of the shortest pre-treatment and the hyperhydricity was very low. The highest number of roots (13.91) were developed after the longest pre-culturing period (34 days, Group 3). Therefore the paclobutrazol is recommended as a pre-treatment before in vitro rooting of Narcissus poeticus subsp. radiiflorus on hormone-free medium.

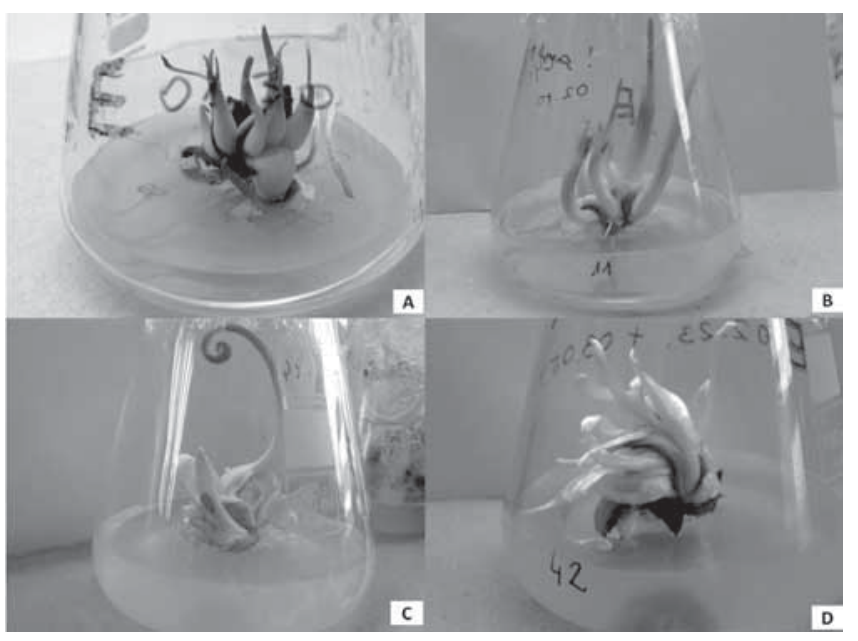

Figure 4. In vitro healthy (A: Group 1, B: Group 2) and hyperhydrated (C, D: Group 3) Narcissus poeticus subsp. radiiflorus bulblets before the last evaluation (photos by: Jámbor-Benczúr)

\section{Acknowledgement}

This work was supported by HAS (Hungarian Academy of Sciences) Scientific Scholarship Programme for Hungarians Abroad.

\section{References}

Artemchuk I.V., Ivanov S.D., Komendar V.I., Stojko S.M., Trybun P.A., Turjanyn I.I. (1966): Karpatskije zapovedniki. Uzhgorod. Izdatelstvo, Karpaty

Chamani E., Hir Y.P., Izadi N., Arshad M. (2012): Effects of Hinokitiol, Paclobutrazol, TDZ and NAA incorporated in media with or without actiated charcoal on narcissus under in-vitro condition. 47th Croatian and 7th International Symposium on Agriculture. Section 4. Vegetable Growing, Ornamental, Aromatic and Medicinal Plants. 88.

Chen J., Hall D.E., De Luca V. (2005): Effects of the growth retardant paclobutrazol on large-scale micropropagation of dayliliy (Hemerocallis sp.). In Vitro Cell. Dev. Biol.-Plant. JanuaryFebruary 41: 58-62.

Chopik V.I. (1976): Ridkisni roslyny Ukrainy. Naukova Dumka, Kyiv

Chopik V.I., Kotov M.I., Protopopov V.V. (1977): Vyznachnyk roslyn Ukrainskyh Karpat

Gavidia I., Pérez-Bermúdez P. (1997): Digitalis obscura cardenolides. Effect of macronutrient concentration and $\mathrm{N}$ source on growth and productivity of shoot-tip cultures. Phytochemistry, 46 (2): 273-278.

Hongxia Cui, Xiaohong Gu, Lei Shi (2009): In vitro proliferation from axillary buds and ex vitro protocol for effective propagation of Syringa x hyacinthiflora 'Luo Lan Zi'. Scientia Horticulturae, 121: 186-191.

Jevcsák M., Kohut E., Ördögh M., Jámborné Benczúr E. (2012): Paclobutrazol hatásának vizsgálata a Leucojum aestivum in vitro szaporítása során. Acta Academiae Beregsasiensis XI. (2): 151-160. Jevcsák M., Ördögh M., Kohut E., Jámborné Benczúr E. (2013): A paclobutrazol hatása a Narcissus poeticus ssp. radiiflorus in vitro tenyészeteire. Kertgazdaság, 45 (1): 29-34. 
Jevcsák M., Ördögh M., Jámborné Benczúr E. (2014): Különböző növekedésszabályozók hatása a Narcissus poeticus ssp. radiiflorus in vitro gyökeresedésére. Kertgazdaság, 46 (3): 36-43.

Kostenko Ju. I., Sheljag-Sosonko Ju.P. (ed.) (1996): Cgervona knyzhka Ukrainy. Roslynnyj svit. Ukrainska Entsuklopedija, Kyiv

Matvejev T.S. (1980): Poliploidnyje dekorativnyje rastenija. Odnodolnyje. Leningrad. Izdatelstvo, Nayka

Mosonyi I. D., Ördögh M., Tilly-Mándy A. (2013): A paclobutrazol hatása Galanthus elwesii Hook mikroszaporítása során. Kertgazdaság, 45 (4): 50-55.

Murashige T., Skoog F. (1962): A revised medium for rapid growth and bioassays with tobacco tissue cultures. Physiologia Plantarum, 15: 473-497.
Nagaraju V., Bhowmik G., Parthasarathy V.A. (2002): Effect of paclobutrazol and sucrose on in vitro cormel formation in gladiolus. Acta Bot. Croat., 61 (1): 27-33.

Vargha A. (2002): Független minták egyszempontos összehasonlítása új rangsorolásos eljárások segítségével. Statisztikai Szemle 80 (4): 328-353.

Vargha A. (2008): Új statisztikai módszerekkel új lehetőségek: a ROPstat a pszichológiai kutatások szolgálatában. Pszichológia 28 (1): 79-100.

Ziman S.M., Bulah O.V. (2009): Nartsys vuzkolystyj. In: D'iduh Ya. P. (Eds.) Chervona Knyha Ukrayiny, Roslynnyj svit, Kyiv: Globalkonsalting. 67. 